\title{
HENRİ DE LUBAC'A GÖRE KİLİSE VE KURTULUŞ*
} İsmet Eşmeli*

\begin{abstract}
Özet
"Henri de Lubac'a göre Kilise ve Kurtuluş" adlı bu makalede öncelikle Hıristiyanlık tarihinde kilise için yapılan genel tanımlamalar hakkında öz olarak bilgiler verilmiştir. Akabinde kilisenin mahiyeti, boyutları hakkında özellikle, son zamanlarda farklı ekol ve mezhebe mensup teologların farklı yaklaşımlarının olduğuna değinilmiştir. $\mathrm{Bu}$ bağlamda çalışmamız, Henri de Lubac'ın kilise anlayışı çerçevesinde kilisenin mahiyeti, misyonu ve kurtuluştaki rolü ile ilgili bilgileri kapsamaktadır. Bu makalenin amacı, 1896-1991 yıllarında yaşamış ve II. Vatikan Konsilinde kilisenin yeniden tanımlanmasında ve misyonun belirlenmesinde etkili olan teologlardan olan Fransız Cizvit teolog Henri de Lubac'ın kilise ve kurtuluş ile ilgili görüşlerini okuyucuların hizmetine sunmaktır. Sonuç’ta ise bir bütün halinde çalışmamızdan elde ettiğimiz bilgiler çerçevesinde analiz yapılarak değerlendirme yapılmıştır
\end{abstract}

Anahtar Kelimeler: Henri de Lubac, Kilise, Hıristiyanlık, İsa, Kurtuluş, Misyon.

\section{Church and Salvation According to Henri de Lubac}

\begin{abstract}
Firstly, İn this article, titled "Church and Salvation According to Henri de Lubac", it is given the general information of made definitions fo the church in the history of Chiristianity. Then, especially in the recent time, it is mentioned that the theologians members of the different sect and school have the different approach of the nature and dimensions of the church. In this context, our work includes the information about the nature and the mission of the church and it's role in the salvation in the context of the church's understanding of Henri de Lubac. The purpose of this article is to provide services to the readers the views of Henri de Lubac on the church and salvation, French Jesuit theologian, lived between 1896-1991 and a theologian of influential theologians in the redefinition of the church and the determination of it's mission in the Second Vatican Council, In the conclusion, it is evaluated the results of this dissertation.
\end{abstract}

Keywords: Henri de Lubac, Church, Chıristianity, Jesus, Salvation, Mission.

\footnotetext{
'Bu makale “Henri De Lubac'ın Kilise Anlayışı, Teolojik Görüşleri ve Katolik İlahiyatına Katkıları(18961991)" adlı doktora tezinin ilgili bölümünün genişletilerek düzenlenmiş halidir.

*Yrd. Doç. Dr, Pamukkale Üniversitesi İlahiyat Fakültesi, iesmeli@pau.edu.tr
} 


\section{Giriş}

İlk zamanlardan günümüze kadar "kilise", İsa'ya inanan, kendilerini ona ve onun yoluna adayan ve İsa'yı kadın-erkek bütün herkes için bir umut olarak düşünen topluluğu ifade etmek üzere kullanılan bir kavramdır. ${ }^{1}$ Hıristiyanlık geleneğinde kilise kavramı, hem kutsal mekânı hem de yerel ya da evrensel Hıristiyan toplumunu ifade etmek için kullanılmıştır. ${ }^{2}$ Ancak, Hıristiyanlık tarihine bakıldığında, "kilise" kavramının, çok geniş yelpaze içerisinde anlaşıldığı ve bu kavrama oldukça geniş anlamlar yüklendiği görülecektir. ${ }^{3}$ Burada, öncelikle "ecclesia" veya "church" kelimelerine yüklenen anlamları incelemek gerekmektedir.

Kilise, kelime olarak Yunanca Ekklesia (Latince Ecclesia) kelimesinden gelmiştir. Ekklesia kelimesi dini anlamda kullanılmaya başlamadan önce yasal olarak sivil halklar toplantısını (meclisi) ifade etmek için kullanılmıştır. Yunanca'da Ekklesia kelimesinin, özel davetiyeli toplantı (meclis), özel iş veya bir amaç için toplumun dışına çağrılmış topluluk anlamında kullanılmakta olduğu görülür. Ekklesia, aynı zamanda Eski Yunanistan'da bir şehirde yaşayan vatandaşların meclisine (halk meclisine) verilen bir addır. ${ }^{4}$

İznik Konsili'nde (325) kilisenin Bir, Kutsal, Katolik (Evrensel) ve Apostolik olmak üzere dört özelliğe sahip olduğu belirlenmiş ve kilise, görülen ve görülmeyen şeklinde de nitelendirilmiştir. ${ }^{5}$ Ayrıca kilisenin birlik, kuruluş/kurum, sakrament, elçi ve hizmetkâr (servant) olmak üzere genel kabul görmüş beş farklı boyutu bulunmaktadır. ${ }^{6}$

Hıristiyan dünyasında farklı kiliselere ve ekollere mensup teologlar tarafından çeşitli açılardan değerlendirilen ve tanımlanan kilise son yüzyıllarda ortaya konulan yaklaşımlarla daha farklı bir değerlendirmeye tabi tutulmaktadır. Katolik Kilisesi'nin kendi içinden gerçekleştirmeye çalıştığı reform gayretleri, kilisenin günümüze uygun bir rol oynaması

\footnotetext{
${ }^{1}$ Hans Küng, The Catholic Church, Çev. John Bowden, The Modern Library, New York 2003, s. 5.

2 Şinasi Gündüz, Din ve Inanç Sözlüğ̈̈, "Kilise” Vadi Yayınları, Ankara 1998, s. 220.

${ }^{3}$ Richard P. McBrien, Catholicism, HarperCollins Publishrs, New Edition, New York 1994, s. 579-582.

${ }^{4}$ Christopher O' Donnell, O.Carm, Ecclesia (A Theolgical Encylopedia of The Church), The Liturgical Press, Collegeville Minnesota, s. 92-93.

${ }^{5}$ Karl Rahner, Encyclopedia of Theology The Concise Sacrementum Mundi, Crossroad, New York 1986, s. 214215.

${ }^{6}$ Avery Dulles, Models of The Church, İmage Books, New York 1987, s. 26-94.
} 
gerektiği düşüncesiyle kilisenin sosyal yönüne dikkat çekmektedir. Cizvit teologların önem verdiği bu boyut özellikle Henri de Lubac'ın yaklaşımlarında kendini göstermektedir. Henri de Lubac'ın kilisenin tabiatına ve misyonuna dair yaklaşımları II. Vatikan Konsili’nde de akis bulmuştur. O, kiliseyi sakramentler vasıtasıyla, özellikle Evharistiya, "sosyal” olarak kabul etmektedir. O, kilisenin ilk dönem kilise babalarının yazıları dikkate alınarak yeniden canlandırılmasını savunmuştur. " "Kilise dışındaki insanların kurtuluşu” hakkındaki görüşleri ile II. Vatikan Konsili'nin diğer mezhep, din ve inançlar ile ilgili tutumunun şekillenmesine katkı sağlamıştır. ${ }^{8} \mathrm{O}$, Katolik olmayanların ferdi kurtuluşundan ziyade bir bütün halinde insanlığın kurtuluşu üzerinde kilisenin rolüne vurgu yaparak kurtuluş ve misyon ilişkisine dikkat çekmiştir. ${ }^{9}$

Henri de Lubac'ın kilise ve kurtuluş anlayışına ilişkin düşüncelerini açıklığa kavuştururken, onun geleneksel kilise anlayışından farklı kendine özgü bir yaklaşıma sahip olduğu bilinmelidir. Dolayısıyla bu çalışmamızda, öncelikle Henri de Lubac'ın kilise ve kurtuluş anlayışıyla ilgili görüşlerini anlaşılır şekilde sunmaya çalışacağız.

\section{Kilisenin Mahiyeti}

Henri de Lubac, kilisenin mahiyeti hakkında geleneksel yaklaşımlardan farklı olarak, kilise hakkında paradoksal bir anlayışa sahiptir. Henri de Lubac, kiliseyi hem ilahî yönüyle hem insanî yönüyle değerlendirmiş ve kilisenin mahiyetiyle ilgili anlayışını bu minval üzere geliştirmiştir. Henri de Lubac, bu konudaki görüşlerine Paradoxe et Mystere de l'Eglise (The Church: Paradox and Mystery) adlı çalışmasında yer vermiştir.

\section{1. Paradoks Olarak Kilise}

Henri de Lubac, kiliseyi hem bir Paradoks hem de bir Sır/Gizem olarak tanımlamaktadır. ${ }^{10}$ Henri de Lubac'a, kilisenin paradoksal ve gizemli doğasını vurgulama becerisini veren şey, onun bir teolog olarak sıra dışı araştırmaya sahip olması ve araştırmasının geniş bir alana dayanmasıdır. ${ }^{11} \mathrm{O}$, Sır/Gizem olması hasebiyle kilisenin, insanın aklının alamayacağı bir şekilde zaman dışı ve doğaüstü bir şey olduğunu ifade etmektedir. ${ }^{12}$ Çünkü kilise, -bu yönüyle- insanoğlunun bilgisinin ulaşabileceği diğer bütün nesnelerden tamamen uzaktadır. Ancak aynı zamanda o, inananlarla alakalıdır ve onlarla

\footnotetext{
${ }^{7}$ Ali İsra Güngör, Cizvitler, Berikan Yayınevi, Ankara 2012, s. 148-149 ve 178-180.

${ }^{8}$ Lumen Gentium, No:16.

${ }^{9}$ Güngör, Cizvitler, s. 148-150; Joseph Ratzinger, Life in The Church and Living Theology, (çev. Micheal J. Miller-M. A. Theol), İgnatius Press, San Francisco 2007, s. 60-62.

${ }^{10}$ Henri de Lubac, The Church: Paradox and Mystery, Çev. James R. Dunne, Ecclesia Press, Paris 1969, s. 1.

${ }^{11}$ Susan K. Wood, Spiritual Exegesis and The Church, T\&T Clark, Edinburg 1998, s. 2-4.

${ }^{12}$ Lubac, The Church: Paradox and Mystery, s. 15.
} 
bağlantılıdır. Kilise, insanoğluna dokunur, temas eder, inananlarda hareket bulur ve inananlara kendilerinden bilgiler verir. ${ }^{13}$ Henri de Lubac, kilisenin bu özelliğinin paradoks olma özelliğinden daha derin, daha anlaşılmaz ve daha temel/asıl olduğunu kabul eder. ${ }^{14}$

Henri de Lubac, İncillerin paradokslarla dolu olduğunu ve dini-manevi gerçekliğin paradoksal bir yapıya sahip olduğunu hatırlatmaktadır. Ona göre, Vahiy, ilk olarak birbiriyle çelişkili gibi görünen iki durumu sunar. $O$, birlik ve farklılık arasındaki ilişkiyi, kişi ile toplum arasındaki ilişki gibi paradoks olarak kabul eder. ${ }^{15}$ Henri de Lubac'a göre, başka paradoks ise, doğa ve doğaüstü arasındaki ilişkidir. ${ }^{16}$

Erken dönem kilise düşüncesine sahip ve mükemmeliyetçi bir teolog olarak Henri de Lubac, kilise hakkında Kilise Babalarının kilise anlayışına paralel olarak, kiliseyi bir zıtlıklar kompleksi gibi ele almıştır. Ona göre, kilise hem ilkbahardır hem sonbahardır. Kilise, hem bir başarıdır hem bir umuttur. Kilise hem kutsanmıştır hem kutsamaktadır. Kilise bütün insanların yeniden bir araya gelmesinden oluşan bir topluluktur. ${ }^{17}$

Paradoks olarak kilise hem ilahîdir hem insanîdir. Henri de Lubac'a göre kilise, yukarıdan gelen ilahî bir hediyedir. Ancak aynı zamanda kilise, insanî olması açısından bu dünyanın bir ürünüdür. $\mathrm{O}$, bu dünyada var olan insanî ve ilahî bir gerçekliktir ve ilahî ve insanî özelliklerin bir arada bulunmasıyla oluşmaktadır. Ona göre, bu yönüyle kilise iki farklı alandan (ilahî ve insanî) barındırdığı özelliği dolayısıyla paradoksal bir gerçekliktir. ${ }^{18}$

Henri de Lubac'ın teolojisinde kilise, ilahî ve insanî boyuta sahip insanlardan oluşan sosyal bir gerçekliktir. Bu sosyal yapı, kendi içerisinde farklılık ve paradokslarla birlikte var olmaktadır. ${ }^{19}$ Ona göre kilise, hem bir mahal hem de bir vasitadır. Bu vesile ile insanlar, birbiriyle İsa'nın doğaüstü kaderi içerisinde günahtan kurtularak kucaklaşacaktır. ${ }^{20}$

\footnotetext{
${ }^{13}$ Wood, Spiritual Exegesis and The Church, s. 73-74.

${ }^{14}$ Lubac, The Church: Paradox and Mystery, s. 14.

${ }^{15}$ Lubac, Paradoxes of Faith, Ignatius Press, San Francisco 1987, s. 13.

${ }^{16}$ Rodulf Voderholzer, Meet Henri de Lubac, Çev. Michael J. Miller ve M. A. Theol, Ignatus Press, San Francisco 2008, s. 117-118; Dennis M. Doyle, Communion Ecclesiology, Orbis Books, New York 2000, s. 5758.

${ }^{17}$ Lubac, Paradoxes of Faith, Ignatius Press, San Francisco 1987, s. 16; Doyle, Communion Ecclesiology, s. 59.

${ }^{18}$ Lubac, The Splendor of The Church, Çev. Michael Mason, İgnatus Press, San Francisco 1999, s. 161.

${ }^{19}$ Lubac, Catholicism, Lancolet C. Sheppard and Sister Elizabeth Englund, İgnatus Press, San Francisco 1988, s. 69.

${ }^{20}$ Lubac, The Church: Paradox and Mystery, s. 2-3.
} 
Birçok zıt ve benzer özellikleri içerisinde barındırması nedeniyle Henri de Lubac, kiliseyi bir paradoks örgüsü içerisinde değerlendirmiştir. Bir bütün olarak kilise, hem anadır hem gelindir hem de damattır. Aynı zamanda o hem sürüdür hem çobandır. ${ }^{21}$

Kilise, bütün yönleriyle paradokstur. Tüm kilise, sadece kurum olarak değil, öğretendir ve öğrenendir, kutsayandır ve kutsanandır. ${ }^{22}$ Daha anlaşı1ır bir cümle ile ifade edecek olursak Henri de Lubac, kiliseyi bu dünya sınırları içerisinde -doğal sınırlar içinde- yaşam bulan ancak aşkınla -doğaüstü ile- da hiçbir zaman bağını koparmayan ve oradan getirdiği kendine has bir takım ilahî özellikleriyle birlikte hayat bulan yaşayan bir canlı olarak kabul etmektedir. Onun kilisesi, yaşayan, çalışan, ibadet eden, aktif, düşünen, araştıran, inanan, umudu olan ve seven bir kilisedir. ${ }^{23}$

\section{2. Sır/Gizem Olarak Kilise}

Henri de Lubac, kiliseyi paradoks ve sır olarak kabul ederek aynı gerçekliğin farklı yönlerini ortaya koymuştur. Henri de Lubac'ın kilise teolojisinde kilise farklı açılardan dolayı sır/gizem olarak nitelendirilmektedir. Onun kiliseyi tanımlamak için kullandığı metaforlar, paradoks ve sır/gizem üzerine bina edilmiştir. ${ }^{24}$ Henri de Lubac'a göre, kilisenin sır/gizem olarak neyi ifade ettiğini, kilise için kullanılan metaforlarla ilişkilendirerek açıklama gayreti içinde olacağız.

\section{2.1. Üçlü Birlik’in (Baba-Oğul-Kutsal Ruh) İşi Olarak Kilise}

Lumen Gentium'un (LG) ilk bölümünde yer aldığı gibi Henri de Lubac, kiliseyi sır olarak açıklarken onu Üçlü Birlik'in işi ve bu işin devamı niteliğinde ele almıştır. Henri de Lubac, kiliseyi bu Üçlü Birlik'in oluşturduğu bir sır olarak algılamıştır. O, kilise konusundaki teolojisini bu anlayış çerçevesinde oluşturmuştur.

Birincisi, kilise Üçlü Birlik'in işi olarak bir sır/gizemdir. Henri de Lubac, "İsa’yı Tanrı'nın* (Baba'nın) sakramenti, kiliseyi de bizim için İsa'nın sakramenti” olarak tanımlarken kiliseyi, onun sır/gizem özelliğine vurgu yaparak değerlendirmiştir. ${ }^{25}$ Kilise, bir sır/gizemdir. Çünkü o, insanın ulaşamayacağı bir zamana sahiptir. Ama aynı zamanda kilise, insanla ilgilidir, insana dokunur ve insana insandan bilgiler verir. Kilise bu özelliklere sahip

\footnotetext{
${ }^{21}$ Lubac, The Church: Paradox and Mystery, s. 6.

${ }^{22}$ Lubac, The Splendor of The Church, s. 106-107.

${ }^{23}$ Lubac, The Church: Paradox and Mystery, s. 4.

${ }^{24}$ Lubac, The Splendor of The Church, s. 127.

* Burada Tanrı kelimesini Baba-Tanrı yerine kullanıyoruz. Bu kullanımla Hıristiyan inancına göre, Baba-OğulKutsal Ruh İlişkisi içerisinde Tanrı'nın sadece Baba olduğu kastedilmemektedir.

${ }^{25}$ Lubac, The Splendor of The Church, s. 18.
} 
olabilmesi için dokunulabilir ve görülebilir bir şekle veya özelliğe sahip olmak zorundadır. Bunun için Tanrı, kurtuluş planının daha etkili ve verimli bir şekilde gerçekleşebilmesi amacıyla, Kelam'ını (İsa) ete kemiğe büründürmüştür. Tanrı'nın görülebilen inayeti ise İsa ve onun yaşamıdır. Böylece Tanrı inayetini görülebilir kılmıştır. Henri de Lubac'a göre, Tanrı'nın görünür Kelam'ı (İsa), Tanrı'nın kurtuluş planının ve kendi varlığının göstergesidir. Bu açıdan İsa, dolayısıyla kilise, sadece herhangi bir sır değil özel bir sır/gizemdir. ${ }^{26}$

Kilise, bir sir/gizemdir. Fakat bu sir/gizem siradan bir sir/gizemden farklılık taşımaktadır. Sır olarak kilise, kendine özgü özelliğe sahip olmak zorundadır. Bu nedenle kilise, Tanrı'dan gelen bir sır/gizemdir ve Tanrı'nın planının hizmetindedir. O, kurtuluş için bir organizmadır. Aynı anda kilise, tümüyle İsa'yla bağlantılıdır ama İsa'dan ayrı olarak herhangi bir varlığa, değere veya etkiye sahip değildir. Böylece kilise, Baba-Oğul-Kutsal Ruh üçlüsünün bir işi olarak mevcudiyet kazanmaktadır. ${ }^{27}$

İkincisi, kilise sır/gizem olarak insanî ve dünyevî sınırların ötesinde ve ötesindendir. Kilise, her zaman doğal sınırlarını aşan bir özelliğe sahiptir. Kilise hakkında konuşulurken hep bir imaj, bir sembol ve bir analojiye ihtiyaç duyulmaktadır. Bu nedenle Henri de Lubac, kilise hakkındaki teolojisini ortaya koyarken genellikle metaforlara başvurmak durumunda kalmıştır. Mesala, Henri de Lubac'ın kilise için kullandığı İsa 'nın Mistik Bedeni metaforu bu durumu ortaya koymaktadir. ${ }^{28}$

Kiliseyi tanımlamak için kullanılan diğer metaforlar da bize kilisenin sadece bu dünyayla sınırlı olmadığını, aksine doğaüstü kaynaklı olduğunu göstermektedir. ${ }^{29}$ Şu da bir gerçektir ki, kilise için kullanılan metaforlar tek başına kiliseyi tanımlamak için yeterli görülmemektedir. Bu nedenle, kilisenin farklı metaforlarla tanımlanma zorunluluğu ortaya çıkmıştır. Bu da, kilise hakkında çalışma yapanları onun insanî ve dünyevî sınırların ötesiyle bir bağlantısının olduğu sonucuna götürmektedir.

Kilisenin "beden", "sosyal bir kurum", "birlik", "ana” gibi metaforlarla izahına baktığımız zaman hep sır/gizem olarak görüldüğü veya hep Baba-Oğul- Kutsal Ruh eksenli bir yapı şeklinde anlaşıldığı görülecektir. Henri de Lubac'ın bu hususta sahip olduğu düşünce de bu bağlamdadır. Henri de Lubac'a göre, “kilise, bizi ölümden kurtaran bir gemidir. Kilise,

\footnotetext{
${ }^{26}$ Lubac, The Church: Paradox and Mystery, s. 14.

${ }^{27}$ Lubac, The Church: Paradox and Mystery, s. 15.

${ }^{28}$ Lubac, The Splendor of The Church, s. 99.

${ }^{29}$ Reinder Bruinsma, The Body of Christ: A Biblical Understanding of The Church, Review and Herald Pub, Assoc 2009, s. 46-47.
} 
Nuh'u tufandan kurtaran bir gemidir. Biz de bu gemide bulunuyoruz. Ancak biz, sadece bu gemideki yolcular değil aynı zamanda gemiyiz yani, biz kiliseyiz. Böylece, kilise bir halk, bir topluluk olmaktadır. Ancak kilise sadece bu birliğin sonucu değildir. Hiristiyan olmak sadece kilise yoluyla olmaktadır. Bu nedenle kilise bir anadır. O bize İsa'da bir yaşam sunar. Fakat bu ana, bizi her zaman karnında tutar ve eşiyle onun birliği o kadar yakındır ki, kilise eşinin bedenidir ve sonuçta biz onun üyeleri oluruz. Kilise, inananların evidir......" 30

Üçüncüsü, bir önceki başlıkta ele alındığı şekliyle kilisenin bir paradoks olmasıdır. Kilise paradoks özellikleriyle zaten bir sır/gizemdir. Kilise Baba-Oğul- Kutsal Ruh ve inananlardan oluşmaktadır. Bu nedenle kilise, hem görülebilir (bu dünyayla ilişkili) hem de görülemez (doğaüstü ile ilişkili) özelliktedir. Ancak Burada şunu belirtmeliyiz ki Henri de Lubac, kiliseyi görülebilen kilise ve görülemeyen kilise olarak iki kategori altında değerlendirmemiş; aynı kilisenin iki farklı özelliğinin olduğunu vurgulamıştır. Kilise hem bu dünyada ve bu zamandadır hem de eskatolojik ve ezelî-ebedîdir. ${ }^{31}$

Kilise, Baba-Oğul-Kutsal Ruh'un (Üçlü Birlik'in) gizemli bir uzantısıdır, dışa vurumudur. Kilise inananları sadece yaşam birliğine hazırlamakla kalmaz. Onların Üçlü Birlik'in davetine katılımına vesile olur. Kilise, sürekli bir bedenleşmedir ve bu dünyada İsa'nın varlığının devamıdır. ${ }^{32}$ Başka bir açıdan kilise, hem cennetseldir hem bu dünyayla ilgilidir. Kilise hem tarihsel ve eskatolojik hem fani ve ezelî-ebedîdir. ${ }^{33}$

\subsection{2. Üçlü Birlik’in (Baba-Oğul-Kutsal Ruh) İşinin Devamı Olarak Kilise}

Henri de Lubac, kilisenin sakramentler aracılığıly, özellikle Evharistiya vesilesiyle Üçlü Birlik'in işinin devamı olduğunu belirtmektedir. ${ }^{34}$ Henri de Lubac'ın teolojisinde Evharistiya önemli bir sakramenttir. Kilise ile Evharistiya Sakramenti arasında önemli bir bağ bulunmaktadır. Evharistiya birliğin oluşmasını sağlayan önemli bir unsurdur. Henri de Lubac, kilise ile Evharistiya'yı birbirinin sebebi-sonucu olarak kabul eder ve Evharistiya kiliseyi, kilise de Evharistiaya'yı ortaya çıkarır ve bunların birbiriyle sebep- sonuç ilişkisi içerisinde olduğunu ifade etmektedir. ${ }^{35}$

Henri de Lubac'a göre İsa, Tanrı'nın sakramenti, kilise ise, inananlar için İsa'nın sakramentidir. Henri de Lubac'ın anlayışında sakramentler Tanrı'nın kurtuluş planının devam

\footnotetext{
${ }^{30}$ Lubac, The Church: Paradox and Mystery, s. 21.

${ }^{31}$ Wood, Spiritual Exegesis and The Church, s. 80-81.

${ }^{32}$ Herbert Vorgrimler, Sacramental Theology, Liturgical Press, 1992, s. 36.

${ }^{33}$ Lubac, The Church: Paradox and Mystery, s. 24.

${ }^{34}$ Wood, Spiritual Exegesis and The Church, s. 85.

${ }^{35}$ Lubac, Corpus Mysticum, Çev. Richard Price ve Christopher Stephens, Universty of Notre Dame Press, Notre Dame İndiana 2006, s.13-14.
} 
etmesi için önemlidir. Evharistiya aracılığıyla inanan, Tanrı'nın kurtuluş planına dâhil olmuş olur ve kilisenin devamına katılmış olur. Böylece, İsa'nın mistik bedeninin, yani kilisenin bir üyesi olur. Evharistiya ve diğer sakramentler, Üçlü Birlik’in işi olarak kilisenin devamını sağlayan önemli bir unsurdur. ${ }^{36}$

\section{Kilisenin Boyutları}

Henri de Lubac, geniş bir teoloji anlayışıyla kiliseyi farklı boyutlarıyla değerlendirmiştir. Henri de Lubac'ın kiliseyle ilgili bu farklı yaklaşımları kilisenin doğası gereği çok boyutlu bir gerçeklik olmasıyla bağlantılıdır. ${ }^{37}$

\section{1. İlahi Boyutu}

Her şeyden önce Henri de Lubac, kilisenin Üçlü Yaşam için bir davet olduğuna vurgu yapmıştır. Dennis M. Doyle, Henri de Lubac'ın: “Tanrı bizi, doğa sınırları içinde kalmamız için zorlamamıştır. Veya terk edilmiş bir bölgede tatmin olmamıza da razı değildir. Aksine Tanrı, bizim Üçlü Yaşam 'ın kalbinde birlikte olmamızdan razıdır. İsa kendisini, bizim ilahî kişilerin birliğinde olabilmemiz için kurban olarak sunmuştur. $\mathrm{Bu}$ dünyadaki şeylerin Üçlüdeki bütün şeylerle bir arada toplandığı bir yer vardır. O da “Tanrı'nın Ailesidir”. Ki o aile, Üçlünün zaman içindeki gizemli uzantısıdır. İnsanlar, Baba-Oğul-Kutsal Ruh birliğinde birleşirler. Yani, onlar tamamen üçlü bir özelliğe sahip olan kilisede birleşirler” ifadelerine yer vererek onun kilise anlayışını aktarmıştır. ${ }^{38}$

Henri de Lubac'a göre, kilise bağlamında çok katmanlı ilişkilerin ilahî şekli, kilisenin ne olduğuyla ilgili olarak öze ulaşılmasını sağlar. Ona göre kilise, kurtuluş ve ilahî yaşam arasındaki en derin bağdır. ${ }^{39}$ Henri de Lubac'ın çalışmalarında bu tema genel itibariyle hep ön planda yer almış ve işlenmiştir. ${ }^{40}$

Henri de Lubac, mahiyetini ele alırken kiliseyi paradoksal ve sır boyutuyla birlikte değerlendirmiştir. Kilise, Tanrı'nın kurtuluş planının tezahürüdür. Üçlü Birlik'in bir ürünüdür. Tanrı'nın bir lütfu, bir hediyesidir. Kilise, Tanrı'dan gelen özelliklere yani, aşkın bir boyuta sahiptir. Kilisenin ilahî boyuta sahip olması, onun Tanrı'sal kaynaklı olduğunu

\footnotetext{
${ }^{36}$ Lubac, Corpus Mysticum, s. 80-83.

${ }^{37}$ Veli-Matti Karkkainen, An Introduction to Ecclesiology, InterVarsity Press, 2002, s. 84.

${ }^{38}$ Doyle, Communion Ecclesiology, s. 63.

${ }^{39}$ Lubac, The Splendor of The Church, s. 174.

${ }^{40}$ Doyle, Communion Ecclesiology, s. 64.
} 
göstermektedir. ${ }^{41}$ Henri de Lubac'ın kilise için kullandığı metaforlar, genel anlamda kilisenin ilahî boyutuyla sıkı bir bağa sahiptir. Sakrament ve Beden metaforu buna örnektir. Henri de Lubac sakrament ve sır olma boyutuyla kiliseyi, şöyle açıklar: "Kilise bir sırdır, yani o Hıristiyan sakramentlerinin hepsinin kaynağıdır. Ve bizzat bu sakrament(kilise), diğer bütün sakramentleri içine alan ve onlara hayat veren en büyük sakramenttir. Bizzat İsa'nın kendisi insan tabiatı açısından bizim için 'Tanrı'nın sakramenti' olduğu gibi, kilise de bu dünyada 'İsa'nın sakramenti' dir". ${ }^{42}$ Beden metaforu ile Henri de Lubac, İsa'nın mahiyetiyle bağlantılı olarak tüm inananların mistik bir şekilde Tanrı'nın (İsa'nın) bedenini oluşturduğunu, İsa'nın da bu bedenin başı olduğunu ifade etmekle yine kilisenin ilahî boyutunu ön plana çıkarmıştır. ${ }^{43}$

\section{2. Sur/Mistik Boyutu}

Henri de Lubac, kilisenin açıklanması için kullanılan imaj ve sembollerin mistik şeklini başarıyla kullanmıştır. Henri de Lubac, İncil'in tamamen literal anlamda olmadığına vurgu yapmış ve kutsal metinlerin dört farklı şekilde anlaşılabileceğini belirtmiştir. ${ }^{44}$

Henri de Lubac'a göre kilise, gerçekten tam olarak insanoğlunun birliğinin ruhsal ve sosyal açıdan yeniden bütünleşmesinin işareti olarak “İsa'nın mistik bedeni”dir. Kilise, İsa’yla o kadar yakın ilişki içerisindedir ki, tam anlamıyla “İsa'nın Gelini”dir. Kilise aynı zamanda, inananların anasıdır. Çünkü kilise, Hıristiyanların İsa'nın bedeni içerisinde doğmasına vesile olmaktadır. ${ }^{45}$

Henri de Lubac'a göre Evharistiya, birliğin sağlayıcısı, kilisenin hem sebebi hem sonucudur. Sır boyutuyla kilise, ilahî özellikleri bulunan Üçlü Birlik'le yakından ilişkilidir. Henri de Lubac, kilisenin Üçlü Birlik'in bir sembolü olduğunu belirtmiş ve şu ifadelere yer vermiştir: “ Sen Baba olarak Tanrı'ya inanıyor musun? Sen Efendi olarak İsa-Mesih'e inanıyor musun? Sen Kutsal Ruh'a inanıyor musun?"46 Bu soruları yönelttikten sonra Henri de Lubac, Üçlü Birlik'in üç unsurunun da inanan açısından önemli olduğuna işaret etmiştir. Henri de Lubac'ın anlayışına göre bu üçlü unsur, Yaratıcı Baba, Kurtarıcı Oğul ve Kutsayıcı Kutsal Ruh şeklinde tanımlanmıştır. ${ }^{47}$

\footnotetext{
${ }^{41}$ Wood, Spiritual Exegesis and The Church, s. 87.

${ }^{42}$ Lubac, The Splendor of The Church, s. 202.

${ }^{43}$ Lubac, The Splendor of The Church, s. 127-128,

${ }^{44}$ Lubac, Catholicism, s. 83-84.

${ }^{45}$ Lubac, Catholicism, s. 67-68; Doyle, Communion Ecclesiology, s. 64.

${ }^{46}$ Lubac, The Splendor of The Church, s. 29.

${ }^{47}$ Lubac, The Splendor of The Church, s. 30.
} 
Kilise, bu üçlü unsurun mistik bir şekilde birliğidir. Henri de Lubac'1n, gerçek anlamda inanan birinin, yukarıda bahsi geçen üçlü unsur bağlamında, yalnız olmadığına ve onun diğer insanlara karşı sorumluluğunun bir bakıma kendisini keşfetmesi için yapılan bir yolcuğa benzediğine vurgu yaptığı belirtilmektedir. Ayrıca ona göre, vaftiz olmakla kiliseye giriş yapan yani, İsa'nın mistik bedenine dâhil olan, bu bedendekilerle tek ve aynı olan umudu paylaşarak aynı çağrıdan sorumludur ve aynı bedenin bir üyesi olmuştur. ${ }^{48}$ Henri de Lubac, bu anlayış çerçevesinde kiliseyi, örgütsel bir sır boyutuyla tanımlamış olmaktadır.

\section{3. Sakramental Boyutu}

Sakramental boyutuyla kilise, Henri de Lubac tarafindan Meditation Sur l'Eglise (The Splendor of The Church) adlı çalışmasında geniş bir şekilde sunulmuştur: “Eğer İsa Tanrı'nın sakramenti ise, kilise de bizim için İsa'nın sakramentidir”. Kilise tam anlamıyla İsa'yı temsil eder ve onu sunar, armağan eder. ${ }^{49}$ Henri de Lubac, kilisenin görülebilen ve görülemeyen elementlerinin (ki bunlar birbirinden ayrılamayacak önemdedir) birlikteliğine büyük önem atfetmiştir. $^{50}$

Henri de Lubac'a göre, Tanrı'nın tarihi halkı kilise ile İsa'nın mistik bedeni olarak kilise birliktedir. Tanrı'nın varlığını ortaya çıkaran İsa'nın varlığını ortaya çıkarır. Ve böylece kilise bir gizem/sır ve bir sakrament olur. ${ }^{51}$ Ona göre, görülebilen ve kusurlu olan kilisenin aynı zamanda tertemiz İsa'nın masum gelini olması da bir paradokstur. Henri de Lubac'ın görüşüne göre kilise, bize sunulan, hediye edilen İsa'dır. ${ }^{52}$

Henri de Lubac'1n üzerinde durmuş olduğu Evharistiya ile kilise arasında kurduğu bağ önemlidir. İlk tarihlerden beri kilisenin, beden olarak en temel bir şekilde tecrübe edildiği aşikârdır. Henri de Lubac'ın vurgulamış olduğu gibi, Evharistiya'nın birliği sağlayan bir sakrament olması ${ }^{53}$ ilk dönem kilise tarihinden beri kabul edilegelmiştir. Henri de Lubac'1n teolojisinde sakramentler, özellikle Evharistiya, Tanrı'nın kurtuluş planı çerçevesinde Oğul İsa'yı kurtarıcı, Kutsal Ruh'u kutsayıcı ve kendisinin de yaratıcı olmasının devamını

\footnotetext{
${ }^{48}$ Jeffrey VanderWilt, A Church Without Borders, The Liturgical Press, Collegeville Minnesota 1962, s. 48-49.

${ }^{49}$ Lubac, The Splendor of The Church, s. 209.

${ }^{50}$ Lubac, Corpus Mysticum, s. 305.

${ }^{51}$ Lubac, The Church: Paradox and Mystery, s. 15.

${ }^{52}$ Lubac, The Splendor of The Church, s. 164.

${ }^{53}$ Lubac, Corpus Mysticum, s. 13.
} 
sağlamaktadır. Bu bağlamda Henri de Lubac, Ekmek-Şarap ayini ile İsa'nın bedeni arasındaki ontolojik bağlantıların oldukça açık ve güçlü olduğunu görülür kılmaktadır. ${ }^{54}$

Henri de Lubac'a göre kilise, sakrament boyutuyla nihai ve değişmeyecek olan bir gerçeklik değildir. Aksine bu boyutuyla kilise, şimdiki zaman ve varlıkla ilgilidir. Böylece kilise, her daim devam etmektedir ve edecektir. ${ }^{55}$ Henri de Lubac, sakramental boyutuyla ilişkili olarak kilisenin beden imajını sakramental ve eklesiyal olmak üzere iki kategoride değerlendirmiştir. Henri de Lubac'ın kiliseyi İsa'nın sakramenti ve bedeni metaforuyla tanımladığı da bilinmektedir. ${ }^{56}$

Henri de Lubac, kilisenin sıkı bir hiyerarşi şeklinde dar anlamda anlaşılmasından yakınmaktadır. Ona göre, Evharistiya ve papazlık arasında önemli bir bağ bulunmaktadır. ${ }^{57}$ Bu hususta Henri de Lubac şöyle der: "bir bedenin tek bir hücresi olmasına rağmen aslında bütün beden var demektir. Kilise birçok yerdedir, ancak birkaç kilisenin varlığı söz konusu değildir. Kilise, bütün parçaları ve bölümleriyle birlikte bir bütündür. Her bir papaz kendi cemaatinin birliğini kurar. Fakat her bir papaz bizzat kendisi diğer mekânlarda aynı ve tek olan kurban olma işlemini takdim eden papaz kardeşlerinin tümüyle birlikte barış ve birlik içerisindedir". 58

Henri de Lubac'a göre kilisenin sakramental boyutu, sadece görünen ve görünmeyen kiliseyi değil, aynı zamanda bütün parçalarıyla birlikte bir bütün olarak lokal ve evrensel kiliseleri de birbirine bağlar. Bu yönüyle, Henri de Lubac'ın inanan için İsa'nın sakramenti olarak kabul ettiği kilise, öncelikle İsa merkezli olmak üzere kiliselerin birliğini sağlamaktadır. Ona göre, bütün kiliseler, İsa'nın sakramenti olarak mevcudiyet kazanmaktadır. ${ }^{59}$

\section{4. Tarihsel Boyutu}

Henri de Lubac, kilisenin yani, İsa'nın mistik bedeninin aynı zamanda Tanrı'nın halkı olduğuna vurgu yapar. O, kilisenin tarihsel boyutunu üç şekilde açıklamıştır: İlk olarak, Hıristiyanlık ile Yahudilik arasındaki bağlantılara dikkat çeker. O’na göre, Hıristiyanlıkta yeni ve tek olan şey, yoktan bir yaratmadan ziyade bir dönüşümdür. İsa, İbrahim’in verdiği sözün tamamlayıcısıdır. Henri de Lubac, bu hususta şunları yazmıştır: "Yahudilik esas

\footnotetext{
${ }^{54}$ Lubac, The Splendor of The Church, s. 210-211.

${ }^{55}$ Lubac, The Splendor of The Church, s. 202-203.

${ }^{56}$ Lubac, Corpus Mysticum, s. 75-100.

${ }^{57}$ Doyle, Communion Ecclesiology, s. 65.

${ }^{58}$ Lubac, The Splendor of The Church, s. 108.

${ }^{59}$ Lubac, The Splendor of The Church, s. 206-207.
} 
itibariyle kurtuluş tasavvurunu Hıristiyanlığa vermiştir. Eğer inananların sayısına bakılırsa, kilise daha çok Yahudi olmayanlardan oluşmuştur. Köklerini Yahudilikten alan ve yoluna Tanrı'nın halkı olarak devam eden kilise, somut ve bedenleşmiş bir tarihe sahiptir’. İkinci olarak, Henri de Lubac'1n, tarihteki kilisenin vaadini, görevini her zaman gerçekleştiremediğini itiraf ettiği görülür. Henri de Lubac'a göre, kişisel düzeyde, kilise üyeleri ve liderleri arasında insanî bir zafiyet vardır. ${ }^{60}$

\subsection{Kilisenin Misyonu}

Kilisenin misyonu, kutsal pasajlarda yer alan metinlerden hareketle belirlenmiş ve buna göre kiliseye bir misyon öngörülmüsstür. $\mathrm{Bu}$ nedenle kilisenin misyonu hakkında kutsal metinler belirleyici bir unsur olmuştur. Henri de Lubac, kilisenin misyonu ile ilgili düşüncelerinde bu durumu göz önünde bulundurarak çağdaş dünyada kilisenin misyonu hususunda yeni arayış ve anlayış içerisine girmiş ve bu misyon anlayışını farklı şekillerde geliştirmiştir.

Çağdaş dünyada kilisenin misyonu, temel yönleriyle kilisenin misyonundan farklı olmamakla birlikte, Henri de Lubac'ın bu konudaki yaklaşımı ya da anlayışı ayrı bir önem taşımaktadır. Henri de Lubac'a göre kilisenin çağdaş dünyadaki misyonu, insanlığın kaybettiği birliğe kavuşmasını sağlayarak bu birliği yeniden inşa etmek ve nihayete (kemale) erdirmektir. $^{61}$ Diğer yandan kilisenin misyonu, çağdaş dünyanın getirmiş olduğu meşgale ve ilerleyen teknik bilim karşısında insanlığın kurtuluşu için Tanrı'nın (Baba) Mesih İsa vasıtasıyla tüm insanlık için ortaya koyduğu inayeti ve kurtuluşu sağlamak ve buna vesile olmaktır. $^{62}$

Henri de Lubac, kiliseye özellikle kilisenin sosyal boyutuna dikkat çekerek misyon yüklemeyi tercih etmiştir. Kutsal metinlerde belirtildiği üzere kilisenin misyonu tüm insanlığın İsa'nın bedeni olmasını sağlamaktır. ${ }^{63}$ Henri de Lubac, sosyal açıdan çağdaş dünyada kiliseye düşen misyonun insanlığın yaratılış birliğinden kaynaklanan Tanrı'nın inayetini ortaya koymak ve bu inayetin farkına varılmasını sağlamaktır. Ona göre, insanlığın yaratılış birliğinin sağlanması kurtuluşun sağlanması açısından kaçınılmazdır. İsa vasıtasıyla

\footnotetext{
${ }^{60}$ Lubac, Catholicism, s. 61.

${ }^{61}$ Güngör, s. 149.

${ }^{62}$ Lubac, Catholicism, s. 234.

${ }^{63}$ Matta, 28:19-20.
} 
insanlığın bozulan birliğinin restore edilmesiyle oluşan kilise, hem kurtuluş için bir vasıtadır hem de yeniden sağlanmış bu birliğin sonucudur. ${ }^{64}$

\subsection{Kilisenin Kurtuluștaki Rolü}

Kurtuluş ${ }^{*}$ teorisi, Hıristiyanlık tarihi boyunca Hıristiyan Teolojisi içerisinde önemli bir yer işgal etmiştir. Henri de Lubac, kurtuluş ile kilise arasındaki ilişkiyi açıklayabilmek için geleneksel kurtuluş anlayışından bazı noktalarda ayrılarak çalışmalarında "bütün insanlığın kurtuluşu", "kilise dişındakilerin kurtuluşu" ve "katolik olmayanların kurtuluşu" hususunda kilisenin rolüne önemli bir yer ayırmıştır.

\subsubsection{Bütün İnsanlığın Kurtulușu ve Kilisenin Rolü}

Bütün insanların kurtuluş vasıtası olarak kilise denilince, ilk akla gelen kilisenin kurtuluş için nasıl bir öneme sahip olduğudur. Nasıl olup da, kilise sadece Hıristiyanların hatta sadece Katoliklerin kurtuluşunu sağlamaktan bütün insanlığın kurtuluşunu sağlayan bir vasıta haline gelir? Henri de Lubac'ın, kilise dişında kurtuluşun olmayacağı düşüncesinden ayrılarak, kiliseyi bütün insanlığın kurtuluş vasıtası olarak gördüğü bir gerçektir. Yukarıda belirtildiği üzere, Henri de Lubac'a göre bütün insanoğlu yaratılışta bir birliğe sahipti. Kilise ise, kaybolan bu birliğin sağlanmış halidir. Ona göre kilise, bütün insanlığa yaratılışta sahip oldukları bu birliği sağlayan bir vasıta ve bir sonuçtur. ${ }^{65}$

Henri de Lubac'ın bütün insanlığın kurtuluşunda kilisenin rolü hakkındaki düşüncesini daha net açıklayabilmek için kiliseyi nasıl tanımlamış olduğu önem taşımaktadır. Bilindiği üzere Henri de Lubac, kiliseyi bir Sır ve bir Sakrament olarak görmektedir. Burada Henri de Lubac, kilisenin bütün insanlığın kurtuluşunu simgeleyen evrensel bir sakrament olduğunu belirtmektedir. ${ }^{66}$ Henri de Lubac'a göre, bütün insanlığın birliği prensibi, bir bireyin diğer bireyden farklı olmaksızın yaratılmış olduğu ilahî bir görüntü olarak anlaşılmaktadır. Ona göre, bu imajı sağlayan ise kilisedir. ${ }^{67}$

Diğer yandan, Henri de Lubac'ın teolojisinde vurguladığı İsa'nın mistik bedeni olarak kilise anlayışı kilisenin görünen ve dar olarak kabul edilen sınırlarını genişletmiştir. $\mathrm{Bu}$ vesileyle İsa’nın mistik bedeni olarak Henri de Lubac'ın kilise anlayışı, kilisenin mistik bir anlamda bütün insanlığı kapsayacak şekilde sunulmuştur. Henri de Lubac, İsa’nın bu mistik

\footnotetext{
${ }^{64}$ Lubac, The Church: Paradox and Mystery, s. 21.

* Kurtuluş hakkında geniş bilgi için bkz. Kemal Polat, "Hıristiyan Kurtuluş Öğretisinde İsa Vasıtasıyla Kurtuluş", Ekev Akademi Dergisi, 2006, Y11: 10, Say1: 27, s. 183-202.

${ }^{65}$ Lubac, Catholicism, s. 222-223.

${ }^{66}$ Lubac, The Splendor of Church, s. 202.

${ }^{67}$ Wood, Spiritual Exegesis and The Church, s. 81-82.
} 
bedeninin sadece ilk yaratılışta tek tek bireyleri değil bir bütün olarak insanlığı kapsadığını belirtmektedir. $^{68}$

Kiliseyi tanımlarken o, her zaman insanoğlunun aşkınla olan bağlantısı çerçevesini ve insanlığın bir bütün olarak kader birliğini temel almıştır. Bu bağlamda Henri de Lubac, Tanrı'nın İsa'yı bütün insanlığın kurtuluşu için bir vasıta kıldığını; kiliseyi de bütün insanlığı kurtuluşa ulaştıracak bir vesile olduğunu ifade etmiştir. ${ }^{69}$

\subsubsection{Kilise Dışındaki İnsanlar ve Kilisenin Rolü}

"Mystici Corporis", genelgesinde kilise, Roma Katolik Kilisesi’yle sınırlandırılmış olmasına rağmen, Henri de Lubac'ın teolojisinde bu sınırlandırma bir bakıma kaldırılmış gibidir. Henri de Lubac, kilisenin tüm insanoğlunu İsa'nın bedeninin üyeleri olmaya çağırdığını düşünmektedir. The Splendor of The Church adlı çalışmasında Henri de Lubac, kiliseyi Roma Katolik Kilisesi olarak ifade etmiş olmakla birlikte daha sonraki çalışmalarında bu düşüncesinden farklı bir kanaate sahip olmuştur. ${ }^{70}$

Henri de Lubac, tüm insanoğlunun Roma Katolik Kilisesi'ne ait olmadığı kanaatinde olduğundan sadece bu kiliseye ait olanların kurtulacağı düşüncesine bir bakıma mesafeli davranarak, inanmayanların (kilise dışındakiler) inayetten mahrum kalacağı fikrine katılmamıştır. Aksine ona göre kurtuluş, İsa vasıtasıyla olacak olan bir şeydir. Henri de Lubac, inanmayanların kurtuluşunda kilisenin rolüne açıklık getirirken tüm insanoğlunun birliğinden hareket etmiştir. ${ }^{71}$

Bazı araştırmacılar, Henri de Lubac'ın bütün insanların Tanrı imajıyla yaratılmış olduğu görüşünden hareketle, insanlar yaratılış biçimiyle bile insan olarak yaratılmış olmalarından dolayı "isimsiz bir şekilde" inayete erişebileceği görüşünde olduğuna dikkat çekmiştir. ${ }^{72}$

Konunun başında belirttiğimiz gibi, kilise dışındaki insanların durumu ile ilgili olarak Henri de Lubac, kilise geleneği içerisinde önceden beri kabul edilen inancın dışına çıkmış, konuya farklı bir noktadan yaklaşmış ve "kilise dışında kurtuluş yoktur" anlayışına yeni bir yorum getirmiştir. Henri de Lubac'a göre kilise, bütün insanoğlunu İsa’nın bedeni olmaya

\footnotetext{
${ }^{68}$ Lubac, Catholicism, s. 25-33.

${ }^{69}$ Lubac, Catholicism, s. 67-68.

* 1943 yılında Papa XII. Pius tarafından yayınlanan ve özetle kilisenin İsa'nın mistik olduğunu vurgulayan bir genelgedir.

${ }^{70}$ VanderWilt, A Church Without Borders, s. 49-50.

${ }^{71}$ Lubac, Catholicism, s. 224-225; Wood, Spiritual Exegesis and The Church, s. 90.

${ }^{72}$ Güngör, Cizvitler, s. 179.
} 
çağırmıştır. Ona göre kurtuluş, İsa vasıtasıyla gerçekleşecektir. Herkes kurtuluşa erecektir. Ancak bu, İsa'nın inayetine bağlıdır. İsa'nın inayeti de evrensel bir durumdur. Henri de Lubac, kiliseye dâhil olmayanların kurtuluş teorisini, “insanoğlunun birliğì" üzerine kurmuştur. İnsan 1rkı tektir. Henri de Lubac'a göre, insanoğlu genel kader erdemliliği ve temel özellikler açısından aynı bedenin üyesidir. Ona göre, aynı bedenin üyesi olmak, ancak insanoğlunun yaratılıştan getirdiği kaybolan birliği tesis etmekle gerçekleşecek bir durumdur. $^{73}$

Henri de Lubac, kilise dışındaki kurtuluşun inananlarla onları birleştiren mistik bir bağ aracılığıyla gerçekleşeceği kanaatindedir. Kilise dışındakiler kurtuluşa ereceklerdir. Çünkü onlar, kurtulmuş veya korunmuş olan insanlığa bitişik olan parçasıdır. Sonuç olarak, Henri de Lubac'ın görünür bir şekilde kiliseye ait olmayanların kurtuluşunun insanoğlu ırkının biricikliği/birliği aracılığıyla olacağı düşüncesine ulaştığı görülmektedir. Bu kurtuluş aynı bedende olan birlik aracılığıyla gerçekleşecektir. Ancak, nihayetinde İsa'nın bedeni ile bütünleşmek yani, Tanrı'nın Mesih İsa aracılığıyla gerçekleştirdiği kurtuluş çağrısına uymak gerekli görülmüştür. Ona göre, kendi istek ve iradeleriyle bu çağrıya uymayanlar kurtuluşa eremeyeceklerdir. $^{74}$

\subsubsection{Katolik Olmayanların Kurtuluşu ve Kilisenin Rolü}

Hıristiyanlık tarihi boyunca kurtuluş ile kilise ilişkisi güncelliğini muhafaza eden bir konudur. "Kilise dışında kurtuluş yoktur" anlayışı Katolikler tarafından genel kabul gören bir anlayış olarak devam etmiştir. "Kilise dışında kurtuluş yoktur" cümlesiyle Katolikler, "kilise" ibaresinden "Katolik" Kilisesi'ni kastetmekteydiler. ${ }^{75}$ Burada "kilise" kelimesinin, evrensel anlamda kullanıldığı da gözden kaçırılmaması gereken bir husustur. ${ }^{76}$

Henri de Lubac'ın Katolik olmayanların ferdî kurtuluşu düşüncesi, kilise teolojisiyle yakından ilgilidir. Henri de Lubac'ın, kiliseyi İsa'nın mistik bedeni ${ }^{77}$ ve İsa'nın sakramenti ${ }^{78}$ şeklinde tanımlamış olması tesadüfî bir durum değildir. Katolik Kilise geleneğine bakıldığında, kilisenin katı ve görülebilir bir sınırının olduğu görülecektir. Bu katı tutumun doğal olarak teolojinin alanına giren hususlarda da kendini göstermesi kaçınılmazdır. Kilise geleneğinde, II. Vatikan Konsili öncesine kadar Katolik olmayanları dışlayan ve kiliseyi

\footnotetext{
${ }^{73}$ Lubac, Catholicism, s. 227-229.

${ }^{74}$ Lubac, Catholicism, s. 93-105.

${ }^{75}$ Rausch, Catholicism, s. 205-206.

${ }^{76}$ Rausch, Catholicism, s. 60.

${ }^{77}$ Lubac, Catholicism, s. 67.

${ }^{78}$ Lubac, The Splendor of Church, s. 202.
} 
hiyerarşik bir yapı olarak kabul eden bir anlayış bulunmaktaydı. ${ }^{79} \mathrm{Bu}$ anlayışa göre, kurtuluşa erebilecek olanlar da Katolik olup bu hiyerarşik yapı içerisinde yer alanlardır. ${ }^{80}$

Henri de Lubac, Yeni Teoloji ${ }^{*}$ akımı çerçevesinde kiliseyi tanımlarken daha önceden var olan bu katı ve görülebilir bir sınıra sahip olan kiliseyi, daha esnek ve onun sınırlarını daha geniş tutarak tanımlamıştır. ${ }^{81}$ Bunun neticesinde Henri de Lubac, kilise teolojisine uygun bir kurtuluş anlayışı geliştirmiştir. Henri de Lubac'1n kurtuluş hususundaki fikri “bütün insanlar Tanrı imajında yaratılmıştır” düşüncesiyle sıkı bir ilişki içerisindedir. Bütün insanlığın insan olmaları temelinden hareketle Henri de Lubac, Tanrı'nın bütün insanlığın kurtuluşunu arzu ettiğini kabul etmektedir. Henri de Lubac, bütün insanlığı topyekün olarak Tanrı’yla bağlantılı bir şekilde ele alarak kurtuluşun ferdî olmaktan daha ziyade, sosyal olduğu görüşüne sahip bir teolog olarak bilinir. ${ }^{82}$

Henri de Lubac'ın bu düşüncede olmasının nedeni gayet açıktır. Ona göre insan, tabiatı gereği sahip olduğu tabiatüstü boyutuyla Katolik olmasa da, inanmayan biri de olsa içerisinde mevcut olan tabiatüstü boyutuyla kurtuluşa ermesi mümkündür. Bir paradoks ustası olan Henri de Lubac'a göre, insan tabiatı da paradoks bir yapıya sahiptir. İnsan, bir yönüyle tabiata aittir ve doğal şartlara göre davranır, diğer bir yönüyle de tabiatüstüne aittir. ${ }^{83}$

Henri de Lubac, Auguste Comte, Ludwig Feuerbach ve Friedrich Nietzsche gibi düşünürlerin aksine, bireyi ne tam tabiata ait, ne de tam tabiatüstüne ait olarak görmüştür. Yine aynı şekilde o, bireyi ne sadece bireyselliğe indirgemiş ne de sadece bireyin topluma feda edildiği sosyalizme indirgemiştir. Kısacası Henri de Lubac, kilise karşıtı olan düşüncelere karşı kendi sahip olduğu teoloji çerçevesinde savunmasını yapmış ve her zaman İsa merkezli sosyal boyutlu bir kilise teolojisini savunmuştur. ${ }^{84}$

Henri de Lubac, kilisenin Katolik oluşunu Roma Katolik Kilisesi geleneğinden farklı bir biçimde anlamlandırmış olması nedeniyle Katolik olmayanların ferdî kurtuluşundan daha ziyade insanlığın bir bütün olarak kurtuluşa erebileceğini savunmuştur. Ona göre, kilisenin Katolik olması evrensel olmasını ifade etmektedir. Buradan hareketle Henri de Lubac,

\footnotetext{
79 John P. Galvin, "Salvation Ouitside of The Church", The Gift of The Church, Edit.: Patrick Granfield, Peter C. Phan, Liturgical Press, 2000, s. 249-266.

${ }^{80}$ Lubac, Catholicism, s. 235-236.

${ }^{81}$ Jürgen Mettepennıngen, Nouvelle Theologie-New Theology, T\&T Clark İnternational, New York 2010, s. 96.

${ }^{82}$ Francis A. Sullivan, Salvation Outside The Church, Poulist Press, New York 1992, s. 175-176.

${ }^{83}$ Lubac, The Church: Paradox and Mystery, s. 24-25.

${ }^{84}$ Paul McPartlan, The Eucharist Makes The Church: Henri de Lubac and John Zizioulas in Dialogue, T\&T Clark, Edinburgh 1993, s. 14-15; Wood, Spiritual Exegesis and The Church, s. 138.
} 
kurtuluşa erdirecek kilisenin sadece Roma Katolik Kilisesi olmadığını deklare etmiş olmaktaydı. Ayrıca Henri de Lubac, kilisenin inananlar topluluğu olarak anlaşılmasına ihtiyaç olduğunu belirtirken, kesinlikle bireylerin önemsiz olduğuna dair bir imada bulunmamıştır. Ona göre, Hıristiyanlıkta bireylerin aşkın kaderi ile insanoğlunun aşkın kaderi arasında ayrılmaz bir unsur, bir bağ bulunmaktadır. ${ }^{85}$ Kurtuluşun vasıtaları olarak sakramentlerin sosyal boyutu olduğu gibi birliği sağlama aracı olma görevi de bulunmaktadır. Hepsinden evvel Evharistiya Sakramenti birliğin sakramentidir. Henri de Lubac, bu sakramentin dindarlığın bireysel biçimden daha ziyade toplumsal düzeyde ortaya çıkmasına vesile olduğu görüşündedir. $\mathrm{Bu}$ nedenle Henri de Lubac, sakramentleri bireysel olduğu kadar sosyal boyutuyla ele almıştır. ${ }^{86}$

\section{Sonuç}

Hıristiyan kilise (ecclesiology) teolojisi, tarihsel süreç içerisinde çeşitli aşamalar geçirmiştir. Kilise kavramına yüklenen anlamlar, kilisenin mahiyetinin ve boyutlarının belirlenmesinde önemli olmuştur. Ayrıca, kiliseye atfedilen özellikler ve kilise için kullanılan metaforlar kilisenin misyonunun ve kurtuluştaki rolünün belirlenmesinde etkili birer unsur olmuştur.

Kilise, Hıristiyanlığın ilk dönemlerinden itibaren inananların üzerinde etkin olmuştur. Ancak zaman zaman kilisenin bu etkinliği zayıflamıştır. Özellikle 20. yüzyılda kilisenin mahiyeti, boyutları, yapısı ve misyonu konusundaki geleneksel yaklaşımlar bağlılarının ihtiyaç duyduğu çağdaş vizyonu sağlayamaz olmuştur. Kilise özellikle bu yüzyılın başlarından itibaren içine girdiği misyon krizini tartışmaya başlamıştır. $\mathrm{Bu}$ ve benzeri konulardaki tartışmalar yeni oluşumların ortaya çıkmasına zemin hazırlamıştır. Henri de Lubac'ın öncülüğünü yaptığı Yeni Teoloji hareketi de bu oluşumlardan biridir.

II. Vatikan Konsili'nde, kilisenin modern seküler dünya şartlarına uygun ve çağın ihtiyaçlarına cevap verebilecek bir kilise teolojisinin geliştirilmesi amaçlanmıştır. Özellikle, kilisenin yeniden tanımlanması, misyonunun yeniden belirlenmesi ve kiliseye ait olmanın sınırlarının daha geniş anlamda anlaşılmasıyla oluşturulan kilise teolojisi, seküler ortamda kilisenin (inananların) ihtiyaçlarına hizmet etmeyi hedeflemiştir. Henri de Lubac da kilisenin özellikle günümüzdeki misyonu ve kurtuluştaki rolü üzerine vurgu yaparak bu alana katk1 sağlayan Cizvit bir teologdur.

\footnotetext{
${ }^{85}$ Wood, The Church as The Social Embodiment of Grace in The Ecclesiology of Henri de Lubac, Marquette University, 1986, s. 274.

${ }^{86}$ Lubac, Catholicism, s. 82-83.
} 
Henri de Lubac, kilise, onun mahiyeti, boyutları ve misyonu konusundaki görüşleriyle Hıristiyanlık dünyasında önemli tesirler icra etmiştir. Genel olarak Yeni Teoloji Hareketi’ne mensup ilahiyatçılar özel olarak da Henri de Lubac gibi Cizvit ilahiyatçılar, kilise anlayışı, kilisenin mahiyeti, sosyal kilise ve kilisenin misyonu konularındaki teolojik görüşleri ve yaklaşımlarıyla Hıristiyan dünyasında devam eden tartışmalara önemli katkılar sağlamışlardır. Henri de Lubac, kiliseyi tanımlarken geleneksel anlayış çerçevesinden çıkarak "görünen kilise-görünmeyen kilise" şeklinde bir ayrım yapmamıştır. O, kiliseye ait olmayı "İsa'nın mistik bedeni” anlayışıyla genişletmiştir.

Henri de Lubac, kurtuluşu İsa'nın bedeninin sosyal birliğine katılım olarak kabul etmektedir. Kurtuluşun bireysel değil, toplumsal olduğunu ifade etmiştir. Henri de Lubac Katolik olmayanların ferdî kurtuluşu fikrini ortaya koymuştur. O, bir bütün olarak insanlığın kurtuluşu fikri üzerinde durmuştur. Kurtuluşun bozulan bu birliğin yeniden tesis edilmesiyle gerçekleşeceğini belirtmiştir. Henri de Lubac, kilisenin özellikle günümüzdeki misyonu üzerine vurgu yapmıştır.

Henri de Lubac'ın kiliseyi yeniden tanımlama, kilisenin diğer dinlerle olan ilişkisini değerlendirme ve kilisenin misyonu ile ilgili konularda Katolik Kilise teolojisine yaptığ eleştiriler, II. Vatikan Konsili'nde sonuç vermiştir. Bu konsilde alınan kararlarda Henri de Lubac, kilisenin sosyal bir yapı olarak tanımlanmasında, kilisenin diğer dinlerle ilgili kapsayıcı yaklaşımın benimsemesinde ve kilisenin misyonunun yeniden belirlenmesinde etkili olmuştur. Henri de Lubac II. Vatikan Konsili'ne Hıristiyan kilise teolojisine bu bağlamda önemli katkılar yapmıştır.

\section{Kaynakça}

Bruinsma, Reinder, The Body of Christ: A Biblical Understanding of The Church, Review and Herald Pub Assoc 2009.

Lubac, Henri de, Catholicism, Çev. Lancolet C. Sheppard and Sister Elizabeth Englund, İgnatus Press, San Francisco 1988.

, Corpus Mysticum, Çev. Richard Price ve Christopher Stephens,

Universty of Notre Dame Press, Notre Dame, İndiana 2006.

, Paradoxes of Faith, Ignatius Press, San Francisco 1987.

, The Church: Paradox and Mystery, Çev. James R. Dunne, Ecclesia

Press, Paris 1969. 
, The Splendor of The Church, Çev. Michael Mason, İgnatius Press, San Francisco 1999.

Doyle, Dennis M., Communion Ecclesiology, Orbis Books, New York 2000.

Dulles, Avery, Models of The Church, İmage Books, New York 1987.

Galvin, John P., "Salvation Ouitside of The Church", The Gift of the Church, Edit. Patrick Granfield, Peter C. Phan, Liturgical Press, 2000.

Gündüz, Şinasi, Din ve İnanç Sözlüğü, “Kilise” Vadi Yayınları, Ankara 1998.

Güngör, Ali İsra, Cizvitler, Berikan Yayınevi, Ankara 2012.

Karkkainen, Veli-Matti, An Introduction to Ecclesiology, InterVarsity Press, 2002.

Küng, Hans, The Catholic Church, Çev. John Bowden, The Modern Library, New York 2003.

Mettepenningen, Jürgen, Nouvelle Theologie-New Theology, T\&T Clark İnternational, New York 2010.

McBrien Rıchard P., Catholicism, HarperCollins Publishrs, New Edition, New York 1994.

McPartlan, Paul, The Eucharist Makes The Church: Henri de Lubac and John Zizioulas in Dialogue, T\&T Clark, Edinburgh 1993.

O' Donnell, Christopher O. Carm, Ecclesia (A Theolgical Encylopedia of The Church), The Liturgical Press, Collegeville Minnesota 1996.

Polat, Kemal, "Hıristiyan Kurtuluş Öğretisinde İsa Vasıtasıyla Kurtuluş", Ekev Akademi Dergisi, 2006, Y1l: 10, Say1: 27, s. 183-202.

Rahner, Karl, Encyclopedia of Theology The Concise Sacrementum Mundi, Crossroad, New York 1986.

Ratzinger, Joseph, Life in The Church and Living Theology, (çev. Micheal J. Miller-M. A. Theol), İgnatius Press, San Francisco 2007.

Sullıvan, Francis A., Salvation Outside The Church, Poulist Press, New York 1992.

Vander-W1lt, Jeffrey, A Church Without Borders, The Liturgical Press, Collegeville Minnesota 1962.

Voderholzer, Rodulf, Meet Henri de Lubac, Çev. Michael J. Miller ve M. A. Theol, Ignatus Press, San Francisco 2008.

Vorgrimler, Herbert, Sacramental Theology, Liturgical Press, 1992.

Wood, Susan K., Spiritual Exegesis and the Church in The Theology of Henri de Lubac, T\&T Clark, Edinburg 1998.

, The Church as The Social Embodiment of Grace in The Ecclesiology of Henri de Lubac, Marquette University, 1986. 